\title{
PENDEKATAN METAKOGNISI SEBAGAI ALTERNATIF PEMBELAJARAN MATEMATIKA
}

\author{
Euis Anih \\ Universitas Mandiri \\ euisanihrangga@gmail.com
}

\begin{abstract}
Learning that challenges students to communicate their ideas will make students try to solve the problems they experience in learning mathematics, but the ability of students to communicate and solve problems is very dependent on their awareness of what they know and how to do this. This is related to their metacognitive awareness. Metacognition is the awareness of our thinking so that we can perform specific tasks, and then use this awareness to control what we do. This research was carried out with the aim of: 1) knowing the achievement of students' mathematical communication skills after using the metacognitive approach compared to those using conventional learning, 2) knowing the increase in mathematical communication skills of students who received learning with a metacognition approach and those who received conventional learning, 3) knowing responses students towards learning by using metacognitive learning. Data were collected from students' mathematical communication skills tests in the form of essay questions and student questionnaires. Questionnaires were given to all experimental class students with the aim of knowing students' responses to mathematics learning using metacognition learning. This research is a quasiexperimental study with an experimental class design, namely Pretest-TreatmentPostest, while the control class is Pretest-Postest. From the results of data analysis with a significant level of $=0.05$, it shows that the achievement of mathematical communication skills of students who get learning with a metacognitive approach is better than conventional learning. The improvement of mathematical communication skills of students who received mathematics learning with a metacognitive approach was better than the mathematical communication skills of students who received conventional learning. The improvement in mathematical communication skills of students who received mathematics learning with cooperative learning of the TGT type was in the medium category, while students who received conventional learning had an increase in the low category. Based on the results of the analysis of student responses to metacognition learning, it shows that students have a positive attitude towards learning mathematics with a metacognitive approach.
\end{abstract}

Keywords: Learning Metacognition, Mathematical Communication Ability.

\section{ABSTRAK}

Pembelajaran yang menantang siswa untuk mengomunikasikan gagasannya akan membuat siswa berusaha menyelesaikan permasalahan yang dialaminya dalam pembelajaran matematika, akan tetapi kemampuan siswa dalam mengkomunikasikan serta memecahkan permasalahannya sangat tergantung pada 
kesadarannya tentang apa yang diketahuinya dan bagaimana melakukannya hal ini berkaitan dengan kesadaran metakognisinya. Metakognisi merupakan kesadaran berpikir kita sehingga kita dapat melakukan tugas-tugas khusus, dan kemudian menggunakan kesadaran ini untuk mengontrol apa yang kita kerjakan. Penelitian ini dilaksanakan dengan tujuan untuk: 1) mengetahui pencapaian kemampuan komunikasi matematika siswa setelah menggunakan Pendekatan metakognisi dibndingkan dengan yang menggunakan pembelajaran konvensional, 2) mengetahui peningkatan kemampuan komunikasi matematika siswa yang memperoleh pembelajaran dengan pendekatan metagognisi dan yang memperoleh pembelajaran konvensional, 3) mengetahui respon siswa terhadap pembelajaran dengan menggunakan pembelajaran metakognisi. Data dikumpulkan dari tes kemampuan komunikasi matematika siswa berupa soal uraian dan angket siswa. Angket diberikan kepada seluruh siswa kelas eksperimen dengan tujuan untuk mengetahui respon siswa terhadap pembelajaran matematika dengan menggunakan pembelajaran metakognisi. Penelitian ini merupakan penelitian kuasi eksperimen dengan desain kelas eksperimen yaitu Pretes-Treatment-Postest sedangkan kelas kontrol yaitu Pretest-Postest. Dari hasil analisis data dengan taraf signifikan $\alpha=0,05$ menunjukan bahwa pencapaian kemampuan komunikasi matematika siswa yang mendapatkan pembelajaran dengan pendekatan metakognisi lebih baik dibandingkan dengan pembelajaran konvensional. Peningkatan kemampuan komunikasi matematika siswa yang mendapatkan pembelajaran matematika dengan pendekatan metakognisi lebih baik dibandingkan dengan kemampuan komunikasi matematika siswa yang mendapatkan pembelajaran konvensional. Peningkatan kemampuan komunikasi matematika siswa yang mendapatkan pembelajaran matematika dengan kooperatif tipe TGT teramasuk kategori sedang, sedangkan siswa yang mendapatkan pembelajaran konvensional peningkatannya termasuk kategori rendah. Berdasarkan hasil analisis respon siswa terhadap pembelajaran metakognisi menunjukan bahwa siswa bersikap positif terhadap pembelajaran matematika dengan pendekatan metakognisi.

Kata kunci : Pembelajaran Metakognisi, Kemampuan Komunikasi Matematika.

\section{A. Pendahuluan}

Salah satu kompetensi atau kemampuan matematika yang harus tercapai adalah kompetensi komunikasi matematis. Komunikasi dalam matematika merupakan salah satu bagian terpenting dalam pembelajaran matematika. Namun kenyataanya seringkali siswa tidak mampu memecahkan suatu masalah matematika ketidakmampuan siswa mengomunikasikan permasalahan matematika tersebut membuat siswa kesulitan memecahkan suatu permasalahan meskipun ia sudah 
Pendas : Jurnal IImiah Pendidikan Dasar, ISSN Cetak : 2477-2143 ISSN Online : 2548-6950

Volume 06 Nomor 01, Juni 2021

menguasai konsep materi dengan baik, karena permasalahan yang ia hadapi menjadi bias.

Pembelajaran yang menantang siswa untuk mengomunikasikan gagasannya akan membuat siswa berusaha menyelesaikan permasalahan yang dialaminya dalam pembelajaran matematika, akan tetapi kemampuan siswa dalam mengkomunikasikan serta memecahkan permasalahannya sangat tergantung pada kesadarannya tentang apa yang diketahuinya dan bagaimana melakukannya hal ini berkaitan dengan kesadaran metakognisinya.

$$
\text { Metakognisi merupakan }
$$

kesadaran berpikir kita sehingga kita dapat melakukan tugas-tugas khusus, dan kemudian menggunakan kesadaran ini untuk mengontrol apa yang kita kerjakan (Jacob, 2000:2). Hal tersebut di pertegas oleh Suherman (Khususwanto, 2008:4) Dengan kemampuan ini seseorang dimungkinkan memiliki kemampuan tinggi dalam mengkomunikasikan serta memecahkan masalah. Metakognisi menyadarkan siswa dalam belajar agar proses pembelajarannya berlangsung optimal. Selain itu, dengan kesadaran metakognisi siswa akan mengetahui langkah-langkah apa yang harus diambil jika mereka gagal dalam menyelesaikan masalah matematika.

Dengan

demikian pembelajaran matematika dengan menggunakan

pendekatan metakognitif mutlak diperlukan untuk menyadarkan siswa dalam menyelesaikan permasalahan matematika maupun mengkomunikasikan permasalahan dalam pembelajaran matematika.

Dari uraian di atas, maka untuk mengetahui sejauhmana pengaruh penerapan pendekatan metakognitif sebagai alternatif pembelajaran dalam meningkatkan kemampuan komunikasi matematis siswa dalam pembelajaran matematika maka perlu diteliti hal sebagai berikut : Apakah Penerapan pendekatan metakognitif dapat meningkatkan kemampuan komunikasi siswa dalam pembelajaran matematika?

\section{B. Metode Penelitian}

Metode yang digunakan di dalam penelitian ini adalah metode kuasi 
Pendas : Jurnal IImiah Pendidikan Dasar, ISSN Cetak : 2477-2143 ISSN Online : 2548-6950

Volume 06 Nomor 01, Juni 2021

eksperimen. Metode kuasi yaitu kelas VIII-A dengan jumlah siswa

eksperimen dipilih untuk melihat

hubungan sebab akibat antara suatu

variabel bebas dengan variabel terikat

yaitu implementasi penerapan

pendekatan metakognitif yang

berpengaruh positif terhadap

peningkatan kemampuan komunikasi

siswa dalam pembelajara matematika

di SMP. Sampel dari penelitian ini

adalah kelas VIII SMP-IT Alamy

Subang.

Dari dua kelas paralel pada kelas

VIII yang ada di SMP-IT Alamy

Subang yang berjumlah 74 siswa,

diambil secara acak sebagai kelas

eksperimen dan kelas kontrol, untuk

dijadikan sampel. Kelas yang

dijadikan kelas kontrol yaitu kelas VIII-

B dengan jumlah siswa 37 siswa dan

kelas yang dijadikan kelas eksperimen
37 siswa. Pada kelas Eksperimen

dilaksanakan pembelajaran

matematika dengan pendekatan

metakognitif, sedangkan pada kelas

kontrol dilaksanakan pembelajaran konvensional.

Teknik pengumpulan data dalam penelitian ini menggunakan data hasil dari instrument, berupa soal kemampuan komunikasi matematis. Penelitian ini menggunakan tekhnik pengolahan data pengujian terhadap instrument soal kemudian data yang dikumpulkan diperoses menjadi data kuantitatif. Tipe tes yang digunakan adalah tes uraian. Tes uraian dipilih dikarenakan kemampuan komunikasi matematis siswa akan lebih terukur dengan jawaban dari pertanyaan berbentuk uraian.

Desain penelitian secara skematis adalah sebagai berikut:

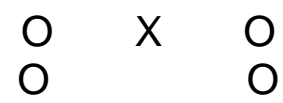

Keterangan:

O : Tes (tes awal dan tes akhir)

$\mathrm{X}$ : Pembelajaran matematika dengan pendekatan metakognitif 
Pendas : Jurnal IImiah Pendidikan Dasar, ISSN Cetak : 2477-2143 ISSN Online : 2548-6950

Volume 06 Nomor 01, Juni 2021

C. Hasil Penelitian

\section{Pembahasan}

Dari serangkaian hasil analisis, diperoleh hasil data pretes dapat dijelaskan bahwa pada taraf signifikansi 0,05 ternyata rata-rata skor pretes antara kelompok eksperimen dengan kelompok kontrol menunjukkan tidak ada perbedaan yang signifikan. Hal ini berarti, kemampuan Komunikasi matematis siswa pada kedua kelompok sebelum dilakukan perlakuan yang berbeda relatif sama. Sedangkan dari analisis hasil postes diketahui bahwa pada taraf signifikansi 0,05 rata-rata skor kedua kelompok menunjukkan terdapat perbedaan yang signifikan. Selanjutnya, setelah diuji satu pihak terhadap hasil postes dengan tujuan untuk mengetahui rata-rata postes

$$
t=\frac{M d}{\sqrt{\frac{\sum d^{2}-\frac{\left(\sum d\right)^{2}}{n}}{n(n-1)}}}
$$

kelompok mana yang lebih baik, diperoleh bahwa pada taraf signifikansi 0,05 rata-rata kelompok eksperimen lebih baik secara signifikan daripada rata-rata kelompok kontrol. Hal ini menunjukkan bahwa pembelajaran matematika dengan penerapan pendekatan metakognitif dapat meningkatkan kemampuan komunikasi siswa dalam pembelajaran matematika dibandingkan dengan pembelajaran dengan cara konvensional.

Untuk mengetahui kualitas peningkatan kemampuan komunikasi Matematis siswa maka digunakan rumus peningkatan (Supriatna: 2011:41) untuk kemampuan komunikasi matematis siswa dengan membadingkan $t_{\text {hitung }}$ dengan $t_{\text {tabel }}$ menggunakan rumus: 
Dengan Rumusan Hipotesis :

$\mathrm{H}_{0}$ : tidak terdapat peningkatan kemampuan komunikasi matematis siswa

$\mathrm{H}_{1}$ : terdapat peningkatan kemapuan komunikasi matematis siswa

Berdasarkan perhitungan pada pembelajaran matematika dengan lampiran D halaman 161 sehingga pendekatan metakognitif di kelas dapat disimpulkan bahwa setelah eksperimen mengalami peningkatan. mendapatkan $\quad$ perlakuan Seperti pada tabel dibawah ini

Hasil Uji Peningkatan Kemampuan Komunikasi Kelas Eksperimen

\begin{tabular}{|c|c|c|c|c|c|}
\hline Jumlah Siswa & $\mathrm{Md}$ & $\sum \mathrm{d}$ & $\sum \mathrm{d}^{2}$ & $t_{\text {hitung }}$ & $t_{\text {tabel }}$ \\
\hline 37 & 3 & 111 & 633 & 6,38 & 1,68 \\
\hline
\end{tabular}

Sedangkan pada pembelajaran peningkatan. Adapun deskripsinya konvensional yang berlangsung di tampak Seperti pada tabel dibawah kelas kontrol tidak mengalami ini:

Hasil uji Peningkatan Kemampuan Komunikasi Kelas Kontrol

\begin{tabular}{|c|c|c|c|c|c|}
\hline Jumlah Siswa & Md & $\sum \mathrm{d}$ & $\sum \mathrm{d}^{2}$ & $t_{\text {hitung }}$ & $t_{\text {tabel }}$ \\
\hline 37 & 0,62 & 23 & 59 & 2,95 & 1,68 \\
\hline
\end{tabular}

Tabel di atas merupakan data untuk melihat peningkatan kemampuan komunikasi matematis siswa mana yang lebih baik dari kedua kelompok digunakan uji peningkatan kemampuan. Dari hasil analisis uji peningkatan kemapuan komuniasi matematis di atas, menunjukkaan bahwa rata-rata peningkatan kemampuan komunikasi matematis kelompok eksperimen dan kelompok kontrol mengalami peningkatanakan tetapi jika dibandingkan kelompok eksperimen mengalami peningkatan 
Pendas : Jurnal IImiah Pendidikan Dasar, ISSN Cetak : 2477-2143 ISSN Online : 2548-6950

Volume 06 Nomor 01, Juni 2021

yang segnifikan dibanding kelompok

kontrol yaitu kelompok eksperimen mengalami peningkatan sebesar 9,43

sedangkan kelompok kontrol

mengalami sebesar 6,38. Maka dapat

ditarik kesimpulan bahwa

pembelajaran matematika dengan

penerapan pendekatan metakognitif

dapat meningkatkan kemampuan

komunikasi siswa dalam

pembelajaran matematika di Sekolah.

Pembelajaran matematika

dengan menggunakan pendekatan

metakognitif dapat meningkatkan

kemampuan komunikasi matematis

siswa lebih baik dikarenakan dalam

proses pembelajarannya dilakukan

tahap diskusi awal yang menuntut

siswa untuk menyadari apa yang

sedang dipelajarinya dengan

memberikan pertanyaan-pertanyaan

"apa yang sedang saya pelajari?",

"betul atau salah pemahaman

saya?”,"kalau salah, bagaimana yang

betulnya?", dengan pertanyaan- pertanyaan inilah mereka akan

mengontrol proses belajarnya,

sehingga melatih siswa untuk

mengingat lebih lama. Pada tahap

kemandirian, siswa belajar untuk

mengaplikasikan pemahamannya

dalam pengerjaan beberapa soal,

sehingga ada proses mengingat,

mengenali kembali bentuk soal yang dihadapinya,

Selain itu, tahapan-tahapan dalam pembelajaran metakognitif yang telah dijelaskan di atas, melatih siswa dalam mengkonstruksi pengetahuannya sendiri dan adanya proses asimilasi (penyerapan) dan akomodasi (menyusun kembali) terhadap pengetahuan yang masuk dalam pikiran siswa. Hal ini sejalan dengan teori belajar konstruktivisme dan teori belajar Piaget.

Selain peningkatan kemampuan komunikasi matematis, dalam penelitian ini diperoleh temuan sebagai berikut : 


\section{Pada Kelas Eksperimen:}

a) Kemampuan Menyatakan situasi, gambar, atau benda nyata ke dalam bahasa, symbol, ide atau model matematik dari 37 siswa yang menjawab dengan benar 7 orang pada pretes (18,9\%) dan 22 orang pada Postes $(59,4 \%)$ maka dengan kata lain siswa mengalami peningkatan sebesar $40,5 \%$.

b) Kemampuan Menjelaskan idea, situasi, dan relasi matematik, secara lisan dan tulisan dari 37 siswa yang menjawab dengan benar 5 orang pada pretes $(13,5 \%)$ dan 18 orang pada Postes (48,6\%) maka dengan kata lain siswa mengalami peningkatan sebesar $35,1 \%$.

c) Kemampuan Mendengarkan, berdiskusi, dan menulis tentang matematika dari 37 siswa yang menjawab dengan benar 1 orang pada pretes $(2,7 \%)$ dan 7 orang pada Postes (18,9\%) maka dengan kata lain siswa mengalami peningkatan sebesar $16,2 \%$.

d) Kemampuan Membaca dengan pemahaman suatu presentasi Matematika tertulis dari 37 siswa yang menjawab dengan benar 4 orang pada pretes $(10,8 \%)$ dan 16 orang pada Postes (43,2\%) maka dengan kata lain siswa mengalami peningkatan sebesar $32,4 \%$.

e) Kemampuan Mengungkapkan kembali suatu uraian atau paragraph matematika dalam bahasa sendiri dari 37 siswa yang menjawab dengan benar 1 orang pada pretes $(2,7 \%)$ dan 13 orang pada Postes (35,1\%) maka dengan kata lain siswa mengalami peningkatan sebesar $32,4 \%$.

\section{Pada Kelas Kontrol:}

a) Kemampuan Menyatakan situasi, gambar, atau benda nyata ke dalam bahasa, symbol, ide atau model matematik dari 37 siswa yang menjawab dengan 
Pendas : Jurnal IImiah Pendidikan Dasar, ISSN Cetak : 2477-2143 ISSN Online : 2548-6950 Volume 06 Nomor 01, Juni 2021

benar 5 orang pada pretes $(13,5 \%)$ dan 11 orang pada Postes $(29,7 \%)$ maka dengan kata lain siswa mengalami peningkatan sebesar $14,2 \%$.

b) Kemampuan Menjelaskan idea, situasi, dan relasi matematik, secara lisan dan tulisan dari 37 siswa yang menjawab dengan benar 3 orang pada pretes $(8,1 \%)$ dan 9 orang pada Postes $(24,3 \%)$ maka dengan kata lain siswa mengalami peningkatan sebesar $16,2 \%$.

c) Kemampuan Mendengarkan, berdiskusi, dan menulis tentang matematika dari 37 siswa yang menjawab dengan benar 2 orang pada pretes $(5,4 \%)$ dan 5 orang pada Postes (13,5\%) maka dengan kata lain siswa mengalami peningkatan sebesar $8,1 \%$.

d) Kemampuan Membaca dengan pemahaman suatu presentasi
Matematika tertulis dari 37 siswa yang menjawab dengan benar 4 orang pada pretes $(10,8 \%)$ dan 7 orang pada Postes (18,9\%) maka dengan kata lain siswa mengalami peningkatan sebesar $8,1 \%$.

e) Kemampuan Mengungkapkan kembali suatu uraian atau paragraph matematika dalam bahasa sendiri dari 37 siswa yang menjawab dengan benar 1 orang pada pretes $(2,7 \%)$ dan 8 orang pada Postes (21,6\%) maka dengan kata lain siswa mengalami peningkatan sebesar $18,9 \%$.

\section{Kesimpulan}

Berdasarkan hasil penelitian, dapat disimpulkan beberapa hal yang berkaitan dengan penerapan pendekatan metakognitif dalam pembelajaran matematika berikut adalah pemaparannya: Terdapat peningkatan kemampuan komunikasi 
Pendas : Jurnal IImiah Pendidikan Dasar, ISSN Cetak : 2477-2143 ISSN Online : 2548-6950 Volume 06 Nomor 01, Juni 2021

matematis siswa yang signifikan antara siswa yang memperoleh pembelajaran matematika dengan menggunakan pendekatan

metakognitif dibandingkan siswa yang memperoleh pembelajaran matematika dengan pembelajaran konvensional. Dengan demikian, Hal ini diperoleh berdasarkan uji- $t$ terhadap nilai peningkatan kemampuan komunikasi matematis siswa dari kedua kelas dengan yang menghasilkan thitung $=5,611$ sedangkan ttabel $=1,688$ maka $t$ hitung > ttabel sehingga $\mathrm{HO}$ ditolak dan $\mathrm{H}_{1}$ diterima. maka dapat disimpulkan bahwa pembelajaran matematika dengan menggunakan pendekatan metakognitif dapat meningkatkan kemampuan komunikasi matematis siswa.

\section{DAFTAR PUSTAKA}
Ansari, Bansul
Komunikasi Matematik, (2009) Banda Aceh: Yayasan Pena Banda Aceh Divisi Penerbitan.

Arikunto, Suharsimi (2007).Dasardasar evaluasi pendidikan, Jakarta: Bumi Aksara.

Agus, Nuniek A. (2007) Mudah Belajar Matematika 2 untuk Kelas VIII Sekolah Menengah Pertamal Madrasah Tsanawiyah, Jakarta: Pusat Perbukuan Departemen Pendidikan Nasional.

Ester, R (2007) Pengaruh pembelajaran kooperatif dengan Teknik Think Pair Square Terhadap peningkatan kemampuan pemahaman da komunikasi matematika siswa SMK. Tesis Program Pascasarjana UPI Bandung. Tidak Diterbitkan.

Gunawan, I (2007). Penerapan Strategi Pakem Dengan Model Pembelajaran Langsung untuk Meningkatkan Hasil Belajar Siswa. Skripsi Jurusan Pendidikan Fisika FPMIPA UPI Bandung. Tidak Diterbitkan.

Harjono, Jojon, (2011) Materi Kuliah Evaluasi Pendidikan, Purwakarta: Tidak Diterbitkan.

Hasanah A (2004) mengembangkan kemampuan pemahaman dan penalaran matematika siswa SMP melalui pembelajaran berbasis masalah yang menekankan pada representasi matematik. Tesis Program Pascasarjana UPI Bandung. Tidak diterbitkan

Karso (1993) Dasar-dasar Pendidikan MIPA. Jakarta: Universitas Terbuka.

Kuntjojo Pengertian Metakognisi http://www.academic.pgcc.edu /wpeirce/MCCCTR /index.html. Diakses pada 21 Agustus 2010. 
Pendas : Jurnal IImiah Pendidikan Dasar, ISSN Cetak : 2477-2143 ISSN Online : 2548-6950 Volume 06 Nomor 01, Juni 2021

Jacob, C. 2000. Mengajar Keterampilan Metakognitif dalam Rangka Upaya Memperbaiki dan Meningkatkan Kemampuan Belajar Matematika. Makalah Disajikan Pada Seminar Aljabar VI Himpunan Peminat Aljabar SeBandung. Jurusan Matematika FMIPA Universitas Parahiyangan Bandung, 21 September 2001.

Kunaepi, Aang, (2011) penerapan model pembelajaran kooperatif tipe Student Team Achievement Divisions (STAD) dalam upaya meningkatkan kemampuan komunikasi matematis siswa, Skripsi jurusan Pendidikan Matematika STKIP Subang. Tidak Diterbitkan

Khususwanto, (2008) Pembelajaran matematika menggunakan pendedkatan metakognitif untuk meningkatkan kemampuan pemecahan masalah matematika siswa, Skripsi Jurusan Pendidikan Matematika FPMIPA UPI Bandung. Tidak Diterbitkan.

Nindiasari, H. 2004. Pembelajaran Metakognitif untuk Meningkatkan Pemahaman dan Koneksi Matematika Siswa SMU Ditinjau dari Perkembangan Kognitif Siswa. Tesis PPS UPI Bandung. Tidak diterbitkan.

Riduan, (2018) Dasar-dasar statistik Pendidikan Jakarta: Alfabeta.

Ruseffendi, E.T. (1980). Pengajaran matematika modern untuk orang tua murid, guru dan SPG. Bandung: Tarsito.
Sudjana. 1992. Metoda Statistika. Bandung: Tarsito.

Suherman, E., dkk. 2001. Common Text Book Strategi Pembelajaran Matematika Kontemporer. Bandung: JICA UPI.

Supriatna, Adang (2011) Pembelajaran Matematika Dengan Pendekatan Investigasi untuk pencapaian kemampuan Berfikir Kreatif siswa. Skripsi Jurusan Pendidikan Matematika STKIP Subang. Tidak Diterbitkan.

Suprihatin, T.(2003) Pengembangan Kemampuan Komunikasi Siswa Melalui Pembelajaran Keterampilan Metakognisi dengan Pemecahan Masalah. Skripsi Jurusan Pendidikan Matematika FPMIPA UPI Bandung. Tidak Diterbitkan.

Suzana, Y. 2003. Pembelajaran dengan pendekatan Metakognitif Untuk Meningkatkan Kemampuan Pemahaman Matematika Siswa SMU. Tesis PPS UPI Bandung. Tidak diterbitkan.

Syah Darwyan, Supardi (2009) pengantar statistic pendidikan, Jakarta: Diadit Media.

Tim Wikipedia, Metakognitif, di http://www.wikipedia /index.html [online]. Diakses pada 12 Desember Agustus 2011.

Tresnowatini (2017) Model Pembelajaran Berbsis Masalah Untuk Mengembangkan Komunikasi Matematis Dalam Interpretasi Kurikulum Smu Berbasis Kompetensi. Skripsi jurusan Pendidikan Matematika FPMIPA UPI. Tidak Diterbitkan. 